Модернізація змістового наповнення дисциплін історико-культурологічного циклу

в контексті цифровізації освіти

УДК 378:37.013.3

\title{
МОДЕРНІЗАЦІЯ ЗМІСТОВОГО НАПОВНЕННЯ ДИСЦИПЛІН ІСТОРИКО-КУЛЬТУРОЛОГІЧНОГО ЦИКЛУ В КОНТЕКСТІ ЦИФРОВІЗАЦІЇ ОСВІТИ
}

\author{
Надія Воронова \\ доктор педагогічних наук, доцент, \\ професор кафедри філософії, історії та соціально-гуманітарних дисциплін \\ ДВНЗ "Донбаський державний педагогічний університет" \\ м. Слов'янськ, Україна \\ ORCID ID 0000-0001-7957-1655 \\ voronova.ns@ukr.net \\ Наталія Шалашна \\ кандидат історичних наук, доцент, \\ доцент філософії, історії та соціально-гуманітарних дисциплін \\ ДВНЗ "Донбаський державний педагогічний університет" \\ м. Слов'янськ, Україна \\ ORCID ID 0000-0002-9110-2680 \\ n.shalashna@gmail.com
}

\begin{abstract}
Анотація. У статті окреслено переваги цифровізації освіти, які вимагають оновлення змісту викладання історико-культурологічних дисциплін. Серед них увиразнено: індивідуалізацію навчання, як можливість для кожного 3 учасників освітнього процесу самостійно обирати темп навчання, час виконання завдань тощо; дотримання принципу антропологізації змістовного наповнення історико-культурологічного знання у вищій школі, що передбачає більшу зорієнтованість змісту викладання на особистість як головного суб'єкта історичного процесу; зміна практик комунікації в освітньому процесі, як вербальних, так і невербальних; розширення доступу до альтернативних джерел інформації, що важливо для критичного аналізу отриманої інформації, критеріїв вірогідності, причин можливої необ'єктивності інформації.

Звернено увагу на поглиблений розвиток інформаційної компетентності, як от здатність до пошуку, аналізу необхідної інформації, здатність самостійно продукувати та поширювати iii. Зазначено, що історико-культурологічні освітні компоненти формують комплекс громадянських та суспільних компетентностей. Наведено перелік електронних інформаційнодовідкових видань 3 історії, культури та мистецтва, створених на основі гіпертекстових посилань та мультимедіа. Особливе місце серед них посіли мультимедійні енциклопедії, віртуальні музеї (путівники), віртуальні екскурсії та галереї. статті висвітлено місце цифрової стратегії у функціонуванні соціально-комунікаційного простору закладу вищої освіти. Автори обгрунтовують необхідність використання цифрових інструментів в університетському навчальному процесі, переходу до нових, цифрових моделей навчання. Цифровізація вищої освіти визначається як необхідна відповідь на суспільні виклики сьогодення. На основі аналізу проблем, що виникають у сфері вищої освіти, автор визначає низку завдань, виконання яких сприятиме процесам цифровізації вітчизняної університетської освіти. У статті розкриваються особливості соціально-комунікаційного простору вищого навчального закладу. Автори детально аналізують його структуру та специфіку функціонування. У межах статті автори
\end{abstract}

() ДВНЗ «Донбаський державний педагогічний університет» 
доводять необхідність розглядати соціально-комунікаційний простір вищого навчального закладу як різновид соціально-комунікаційного простору освіти в цілому. Авторами доводиться необхідність розробки гнучкого соціально-комунікаційного простору з цифровим компонентом, орієнтованого на розвиток світу комунікаційних взаємовідносин в освітній системі.

Ключові слова: цифровізація; індивідуалізація; антропологізація; змістове наповнення; історія; культура; оновлення.

Постановка проблеми в загальному вигляді. Сучасний процес цифровізації освіти ставить нові вимоги перед організацією освітнього простору вищої школи. Здатність повністю реалізувати потенціал новітніх освітніх технологій - одна з ключових вимог до реалізації успішної професійної кар'єри та особистісного розвитку в умовах сучасного світу. Відповідно системність у підході до створення ефективного освітнього середовища в рамках навчального закладу та на рівні викладання конкретних змістових ліній $є$ актуальною вимогою часу. Отже, постійне оновлення змістового наповнення курсів $\epsilon$ необхідністю і потребує постійної й пильної уваги як авторів теоретичних досліджень, так i педагогів-практиків. Водночас завдання модернізації змістового наповнення дисциплін історичного та культурологічного циклів можуть бути вирішені лише комплексно, оскільки історичний розвиток культури $€$ вагомою складовою загального історичного процесу, водночас історичний процес одним із головних рушійних факторів має розвиток культури. Вивчення дисциплін історико-культурологічного циклу здобувачами вищої освіти відіграє одну 3 провідних ролей в професійному та особистісному становленні майбутнього фахівця, оскільки повноцінне опанування цього циклу забезпечує здатність особистості робити самостійні висновки та оцінки, формулювати власне відношення до процесів, які відбуваються в суспільстві. Отже, модернізація змістового наповнення курсів історії України, історії української культури, історії світової культури, естетики є безумовно актуальним на сьогодні.

Аналіз останніх досліджень і публікацій. Проблема вдосконалення викладання історико-культурологічних дисциплін у вищій школі $є$ сьогодні безумовно актуальною, тому привертає пильну увагу дослідників. На сьогодні в педагогічній науці існують сформульовані теоретичні підходи до розробки змістового наповнення цих дисциплін у зв'язку із тими суспільними задачами, які ними вирішуються, зокрема в працях таких авторів, як Н. Барановська, В. Вашкевич, І. Селищева, О. Струкевич. 
Проблеми гуманітарної освіти, культурологічної та історичної підготовки майбутніх учителів з акцентом на змістове наповнення матеріалу та його впливу на розвиток особистості представлено в дослідженнях Т. Вінник, І. Зязюна, Л. Кондрацької, Л. Масол, Н. Миропольської, О. Шевнюк. Теоретикометодологічні засади та моделі історичної та культурологічної підготовки в закладах вищої освіти, методичне забезпечення історико-культурологічної освіти фахівців різного спрямування пропонують Т. Зюзіна, В. Маслов, Н. Костриця. Низка досліджень присвячена історико-культурологічним основам вивчення гуманітарних предметів у школі та методичним аспектам викладання (Л. Аристова, Л. Масол, Н. Миропольська, О. Щолокова).

Проблеми використання інформаційно-комунікаційних (цифрових) технологій в сучасній історико-культурологічній освіті, впливу цифрової культури на організацію освітнього процесу, залучення електронних навчальних засобів, цифрових освітніх ресурсів, створення цифрового освітнього середовища професійної підготовки майбутніх фахівців практично залишаються поза увагою дослідників. Проте саме цифровізація освітнього процесу в умовах розвитку інформаційного суспільства може бути реальним чинником модернізації змістового наповнення дисциплін історико-культурологічного циклу в умовах цифровізації освіти.

На сьогодні вітчизняними й зарубіжними вченими напрацьовано значний обсяг матеріалу щодо інформатизації та цифровізації освіти: концептуальні проблеми інформатизації освіти досліджено в численних наукових розвідках вітчизняних (Биков, 2008) та зарубіжних (Brown, 2017; Dobbin, 2016; Lynch, 2018) учених.

Грунтовні розвідки вітчизняних учених присвячено використанню інформаційно-комунікаційних технологій у вищій професійній освіті (В. Биков (2012), Л. Гаврілова (2017), Г. Лаврентьєва (2013), С. Литвинова (2013), В. Любарець (2016), М. Шишкіна (2013), формуванню інформаційнокомунікаційної (цифрової) компетентності майбутніх фахівців (Л. Карташова (2018)).

Не залишаються поза увагою науковців і дослідження різних аспектів цифрової культури як феномену інформаційного суспільства (Воронова, 2017; Литвинова, 2013; Brown, 2017). Проте комплексне рішення проблеми модернізації змістового наповнення викладання історії, культурології та історії культури на сьогодні ще розроблене недостатньо. 
Модернізація змістового наповнення дисциплін історико-культурологічного циклу в контексті цифровізації освіти

Формулювання цілей статті (постановка завдання). Метою статті $\epsilon$ аналіз необхідних напрямків модернізації змісту викладання дисциплін історико-культурологічного циклу в умовах цифровізації навчання.

Методи дослідження. Дослідження здійснювалось за допомогою методів теоретичного аналізу і синтезу для виявлення суспільних потреб в оновленні змісту викладання історичних та культурологічних дисциплін, можливостей застосування інтерактивних цифрових технологій та викликів, які вони породжують; концептуально-порівняльного аналізу для дослідження можливостей міждисциплінарної інтеграції та результатів застосування цифрових технологій освіти.

Результати дослідження. Інтеграція України в світовий простір вимагає постійного підвищення якості освітніх послуг, в тому числі і постійного оновлення змісту освіти у відповідності до актуальних запитів суспільства. Також однією з ключових вимог $є$ впровадження інноваційних технологій та прийомів освіти, в тому числі й засобів цифровізації. Крім того, сучасні випускники вищих навчальних закладів окрім високого рівня теоретичних $\mathrm{i}$ практичних знань мають володіти здатністю самостійно знаходити, аналізувати та застосовувати необхідну інформацію. Належний рівень володіння інформаційною компетентністю передбачає впевнене і критичне застосування інформаційно-комунікаційних технологій для створення, пошуку, обробки, збереження, обміну інформації, здатність до алгоритмічного мислення, навички дотримання безпеки в цифровому просторі. Крім того, інформаційні компетентності є трансферними, тобто можуть застосовуватись протягом всього життя в різноманітних ситуаціях. Активна цифровізація суспільства та освітнього простору визначає декілька напрямів модернізації змісту викладання історико-культурологічних дисциплін.

Першим напрямом модернізації змісту викладання історичних та культурологічних дисциплін в умовах цифровізації освіти є забезпечення виконання головного суспільного завдання, яке стоїть перед викладачем цих дисциплін, а саме формування комплексу громадянських та суспільних компетентностей, глибинного усвідомлення здобувачами освіти власної історичної та громадянської суб'єктності, активної готовності до примноження досягнень національної культури. Виконання цього завдання можливе лише в умовах організації всього змісту навчального матеріалу довкола особистості як активного суб'єкта історичного та культурного процесу. Навички критичного мислення, самостійний аналіз фактів національної історії та культури, розуміння

Професіоналізм педагога: теоретичні й методичні аспекти. Методичні матеріали до проєкту «Цифровий освітній простір: українсько-польський досвід». - Слов’янськ, 2021. 
естетичних категорій мають активно застосовуватись усіма учасниками освітнього процесу. При цьому цифровізація освіти ставить свої вимоги до змісту викладання дисциплін історико-культурологічного циклу. Проблема полягає в тому, що в умовах цифрового простору зазнає суттєвих трансформацій феномен історичної пам'яті та суспільного історичного знання. Цим структурам стають притаманними якості атомізації, девальвації цінностей, тривіалізації, комерціалізації тощо. Тим важливіше модернізувати зміст викладання таким чином, щоб відновити «зв’язок часів», системність бачення національної історії та культури. Відповідно зміст освіти має вибудовуватись довкола особистості 3 активною громадянською позицією, глибинним усвідомленням цінностей національної культури. Комплекс необхідного до засвоєння теоретичного знання має постійно поєднувати сучасність і минуле, підкреслювати витоки сучасних історичних процесів та явищ культури, закоріненість як сучасних проблем, так $\mathrm{i}$ досягнень в історико-культурній традиції.

Розвиток комп'ютерних технологій привів до виникнення електронних інформаційно-довідкових видань, створених на основі гіпертекстових посилань та мультимедіа. Особливе місце серед них посіли мультимедійні енциклопедії, віртуальні музеї (путівники), віртуальні екскурсії та галереї. Мультимедійні енциклопедії з історії, культурології та окремих видів мистецтва належать до спеціалізованих галузевих енциклопедичних видань, які містять значний обсяг теоретичних, історичних, бібліографічних відомостей 3 відповідної галузі культури, історії чи мистецтва, різних художньо-естетичних жанрів і напрямків.

Віртуальні музеї (путівники залами музеїв) - це колекції цифрових зображень, звукових файлів, текстових документів та інших даних історичної, наукової чи культурної цінності, які є доступними через електронні медіа та надають доступ до віртуальних шедеврів світової художньої культури.

Віртуальні екскурсії та галереї надають можливості перегляду i/aбо прослуховування мультимедійних даних (фото, аудіо, відео, анімація, 3Dзображення та ін.). За допомогою фото-, відео- та аудіоматеріалів віртуальної галереї чи екскурсії можна переглянути експонати, прослухати їхню історію та оцінити їхній стан, тобто отримати вичерпну інформацію про експонати.

На сьогодні створено значну кількість інформаційно-довідкових електронних видань з історії, культури та різних видів мистецтва, які доцільно використовувати в змістовому наповненні навчального матеріалу. Надамо загальний огляд наявних цифрових ресурсів указаного типу з історії, культури та різних видів мистецтва.

() ДВНЗ «Донбаський державний педагогічний університет» 
Інформаційно-довідкові цифрові видання історико-культурологічного змісту:

1. «Перлини української культури» (2006) - мультимедійний проєкт, розроблений компанією «Атлантік» на замовлення Міністерства культури i мистецтв України. Проєкт представлений на п’яти дисках: «Культурна спадщина України» (відомості про вітчизняні музеї, заповідники, пам'ятки історії та архітектури, екскурсії залами музеїв та галерей); «Образотворче мистецтво» (українське мистецтво XX - початку XXI століття, зокрема український авангард, нефігуративний живопис та ін.); «Академічна музика» (розповіді про найвідоміші українські театральні та концертні заклади, провідних вітчизняних музикантів-виконавців, доповнені фотогалереєю та фрагментами музичних творів); «Народна музика» (презентація творчості народних вокальних та інструментальних колективів різних регіонів України); «Популярна музика» (зріз української рок-культури з фотогалереєю та добіркою пісень).

2. Мистецький проєкт «Моя Україна. Берви» $(2002-2017$ рр.) - антологія автентичної української народної культури, що на $21 \mathrm{CD}$ демонструє жанровий та мелодико-ритмічний перелік творів традиційної культури (весілля, колискові пісні, українські народні казки тощо) певних регіонів. Онлайн-версію проєкту можна знайти за посиланням http://bervy.org.ua/. Проєкт реалізовано агентством «Арт Велес» у співпраці з Міністерством культури України. Ця антологія фактично $є$ музичною енциклопедією української традиційної культури в сучасному цифровому оформленні та дизайні. До кожного диска додано кольоровий буклет 3 текстами українських творів та фотоматеріалами вітчизняної давнини. Мультимедійний контент проєкту вміщує: музичнопоетичну творчість; кобзарсько-лірницьку традицію; інструментальну музику; народне малярство; народну архітектуру; писанкарство; народне вбрання; вишивкарство; кераміку і гончарство; ткацтво і килимарство; декоративні розписи; дереворізьблення; художні вироби з металу.

3. Мультимедійна енциклопедія «Світова художня культура»-електронне навчальне видання створене для підтримки викладання відповідного курсу у закладах вищої освіти та художньої культури у 10-11 класах шкіл. Воно складається 3 кількох розділів: мультимедіа каталог - база даних мультимедійного контенту; редактор для самостійного створення альбомів електронних наочних посібників; альбом - засоби для презентації створених власноруч колекцій; довідково-бібліографічні розділи та запасник для самостійної роботи з графічними, музичними і відео об'єктами. Така структура 
енциклопедії дає можливість i педагогу, i студентам (учням) проявити самостійність та творчу ініціативу при вивченні культурологічних дисциплін.

4. Артпроєкт «Історія мистецтв» (http://www.artprojekt.ru, започатковано 2005 року, від арт-компанії «Прометей») - історико-культурологічний онлайн проєкт, що занурює користувачів у мистецтво від найдавніших часів до сьогодення (великі цивілізації, мистецтво Свропи, традиційне мистецтво Сходу та культуру XX століття. На сайті також представлена школа образотворчого мистецтва, архітектура i дизайн, література, віртуальні подорожі галереями світу.

Сучасні освіті резерви цифровізації надають незрівнянно кращі можливості для освоєння досягнень загальносвітової історії та культури. Проте водночас розуміння глобальності історико-культурного процесу несе загрозу цінностям історії та культури національної. Тому усталені в науці категорії народу, нації, національної культури, держави в жодному разі не мають розумітись абстрактно, натомість оновлюючи зміст викладання історикокультурологічних дисциплін, слід надавати цим категоріям сенсу спільнот, що складаються із самоцінних особистостей, об'єднаних спільною системою цінностей, які перебувають в постійному процесі взаємозбагачення. В контексті цифровізації освіти вказане завдання допомагають вирішувати різноманітні простори для особистісного спілкування, як спеціалізовані освітні, так i загальносуспільні.

Адекватне розуміння національної історії та культури можливе лише в загальнолюдському контексті. Відповідно модернізація змісту викладання історико-культурологічних дисциплін має відбуватись також i в напрямку міжпредметної інтеграції історії України та історії української культури із залученням матеріалу всесвітньої історії та історії світової культури, а також етики та естетики. Лише за такої умови можливо досягнути суттєвого прирощення історичного знання отриманого здобувачами освіти на попередньому етапі, тобто в рамках середньої або професійної освіти. Слід домагатись не стільки примноження кількості фактів, засвоєних здобувачами освіти, скільки формування системного уявлення про історичний та культурний процес на землях України як складової частини загальносвітової історії та культури. Лише таким чином історико-культурологічне знання зможе дати молодій людині достатній обсяг теоретичних знань та системних світоглядних переконань, щоби забезпечити водночас самоусвідомлення в контексті національної культурно-історичної традиції та залучення до світових економічних, політичних та культурних процесів. Цифровізація освіти надає для 
цього найширші можливості. Можливість за допомогою засобів цифрової освіти отримати доступ до найрізноманітніших джерел інформації, баз даних, онлайнбібліотек, можливість реалізувати академічну мобільність в умовах дистанційної освіти безумовно, розширюють світоглядні горизонти юнацтва і формують відчуття відкритого загальносвітового культурного простору.

Проте відкритість світового простору культури несе в собі і певну небезпеку дегуманізації особистості, втрати індивідуальності. Запобігти цьому також певною мірою можливо через оновлення змісту викладання історикокультурологічних дисциплін. Зокрема, слід ширше залучати до змістового наповнення вказаних дисциплін матеріал стосовно сучасної культури цифрового суспільства, ролі цифрових засобів комунікації в сучасній масовій культурі, впливу новітніх способів поширення інформації на розвиток суспільної моралі та естетики тощо. Завдяки цьому з'являється можливість подолати певний ментальний розрив між історичною спадщиною суспільства та життєвим досвідом сучасної молодої людини, сформувати у молоді органічне відчуття власної зануреності в культуру в її новітніх формах. В свою чергу наближення історико-культурологічного знання до життєвого особистісного досвіду забезпечує розвиток цілої групи важливих компетентностей, які можуть бути підсумовані як здатність до організації успішної комунікації як діалогу. Цифровізація освіти дає можливість включити найрізноманітніші повсякденні практики в освітній процес через використання можливостей мікроблогів, соціальних мереж тощо, виокремивши в цих повсякденних практиках моральноестетичний елемент та акцентувавши увагу на повсякденному житті як частині суспільного історично-культурного процесу. Відповідно для молодої людини врахування іï приватних інтересів та мотивів поведінки, індивідуально важливих вчинків та їх наслідків формує світоглядно-ціннісну установку на визнання історичної і культурної суб'єктності за кожним членом громади, а отже, розвинути повагу до різноманіття людського суспільства.

В умовах цифровізації освіти важливим завданням вищої освіти $\epsilon$ формування й розвиток практичних навичок із пошуку та аналізу необхідної інформації, а також здатності самостійно продукувати та поширювати інформацію. Оновлення змісту викладання історико-культурологічних дисциплін має відбуватись також і в контексті розвитку поглиблення цих компетентностей. Успішне оволодіння цим комплексом знань забезпечать у подальшому високий рівень здатності до самоосвіти впродовж всього життя. Якісний інформаційний пошук має бути обов'язковою передумовою кожної 3 
форм самостійної роботи здобувачів освіти, а також включатися в зміст навчальних завдань на різних етапах курсу як самостійна форма навчальної роботи. При цьому дуже важливо домогтись набуття навичок саме якісного інформаційного пошуку, тобто усвідомленого пошуку інформації чітко визначеного змісту, рівня релевантності, відповідності навчальним завданням, повноти та актуальності. Тобто навичок попередньої критичної оцінки інформаційних ресурсів та проектування результатів інформаційного пошуку. В контексті історико-культурологічних дисциплін необхідно сформувати чітке розуміння відмінності між історичним джерелом та науковою літературою, різниці між науковим та публіцистичним текстом та можливостями їх використання в навчальному процесі.

Оновлення змістового наповнення викладання історико-культурологічних дисциплін в контексті цифровізації освіти потребує також i оновлення традиційних для цих дисциплін навичок роботи 3 історичними джерелами. Зокрема, суттєвого оновлення потребує зміст навчальних тем, які планується викладати із застосуванням історичних джерел, оскільки самостійний аналіз історичного джерела передбачає попередню достатню обізнаність здобувачів із загальним змістом матеріалу. Зміни в програмі середньої освіти, зокрема постійна інтеграція історії України та всесвітньої історії, яка здійснюється активно останнім часом, вимагають оновлення комплексу пропонованих вищою освітою для опрацювання історичних джерел. Вказане оновлення має відбуватись в напрямку суттєвого розширення комплексу джерел, оскільки цифровізація освіти дає можливості доступу до оцифрованих архівів. Крім того, суттєвого оновлення має зазнати характер та тематика історичних джерел, в тому числі в контексті цифровізації освіти. Зокрема, доцільним $є$ відбір таких історичних джерел, які б висвітлювали приклади соціальної взаємодії людей у повсякденних практиках, свідчили про індивідуальний досвід особистості, індивідуальні творчі досягнення. Цифровізація освіти надає для цього значні можливості, даючи доступ до приватних архівів. Можливість достатньо широко використовувати історичні джерела особистісного характеру, матеріали усної історії, візуальні та аудіо-джерела, а також новітні види джерел - публікації в електронних засобах масової інформації та онлайн-документи дає можливість розширити усвідомлення особистісної включеності в історичний процес, поглибити навички соціальної взаємодії та емпатії.

Водночас оновлюючи зміст викладання історико-культурологічних дисциплін в аспекті використання різноманітних історичних джерел, в тому числі й особистісного характеру, слід пам'ятати про важливість критичного

() ДВНЗ «Донбаський державний педагогічний університет» 
аналізу отриманої з джерел інформації, критеріїв вірогідності, причин можливої необ'єктивності цієї інформації. Цифровізація освіти і тут надає широкі можливості для здійснення критичного аналізу джерел, розширюючи доступ до різноманітних альтернативних джерел інформації, онлайн-енциклопедій, можливості публічного обговорення інформації історичного характеру тощо. Також важливо враховувати те, що в процесі роботи над історичними джерелами, особливо історичними джерелами особистісного характеру, у здобувачів формується усвідомлення того, що створені індивідуальною творчою активністю тексти з часом також стають історичними джерелами для майбутніх поколінь, а отже, розвивається більш відповідальне ставлення до продукованих змістів та їх поширення.

Цифровізація освіти докорінно змінює практики комунікації в освітньому процесі. Змінюється як вербальна, так і невербальна комунікація між всіма учасниками освітнього процесу. Цифрові можливості суттєво розширюють можливості вербальної комунікації як в часі, так і в просторі, створюючи можливості відкладеної вербальної комунікації, поширення вербального повідомлення на значно ширшу аудиторію. Те ж стосується невербальної комунікації - вона збагачується незрівнянно, отримуючи нові форми та засоби. Відповідно формується принципово новий рівень соціальних комунікативних навичок та кооперативних умінь учасників освітнього процесу. Однак такий рівень комунікації також вимагає суттєвого оновлення змісту викладання історико-культурологічних дисциплін. Зокрема, в зміст як лекційного матеріалу, так і завдань для практичної та самостійної роботи варто вводити контент, який стосується ролі комунікації в культурі, залежності історичного процесу від рівня організації комунікації в суспільстві, процесу комунікації як самостійного культурного феномену, відповідальності кожного 3 учасників процесу комунікації за зміст та форму повідомлень, правила онлайн-спілкування та цифрового етикету.

Ще однією суттєвою перевагою, яку надає цифровізація освіти і яка в свою чергу вимагає оновлення змісту викладання історико-культурологічних дисциплін, $є$ індивідуалізація навчання, тобто можливість для кожного 3 учасників освітнього процесу самостійно обирати темп навчання, час виконання завдань тощо. Вказана перевага може бути розкритою повністю лише за умови дотримання принципу антропологізації змістовного наповнення історикокультурологічного знання у вищій школі. Цей принцип передбачає якомога більшу зорієнтованість змісту викладання на особистість як головного суб'єкта 
історичного процесу, зокрема повного висвітлення різноманітності мотивів діяльності кожного з учасників історичного процесу, ролі кожної із суспільних груп, незважаючи на відмінність їх кількісного складу. Окрім аналізу мотивів тих або інших вчинків, що мали історичне значення, в зміст історикокультурологічних дисциплін варто вводити матеріал стосовно наслідків історично значущих дій для індивідуума та групи. Такий зміст допоможе в умовах індивідуалізації навчання не втратити розуміння учасниками освітнього процесу відповідальності індивідуума за результати своєї роботи та залежності колективних результатів від індивідуальної активності кожного з учасників групи.

Крім того, індивідуалізація навчального процесу в умовах цифровізації освіти посилює мотивацію до прояву власних творчих здібностей і надає вагомий інструментарій для реалізації творчого потенціалу. Відповідно змістовне наповнення історико-культурологічних дисциплін варто оновити, надавши конкретні приклади впливу творчої активності особистості на перебіг та наслідки історико-культурного процесу. Надання таких прикладів, в свою чергу, можливо значно унаочнити завдяки застосуванню новітніх цифрових технологій.

Висновки 3 дослідження і перспективи подальших розвідок у цьому напрямі. Проведене дослідження засвідчило, що дисципліни історикокультурологічного циклу мають певну специфіку, яка проявляється в умовах цифровізації освіти і для своєї повноцінної реалізації вимагає оновлення змістового наповнення викладання цих предметів. Історико-культурологічне знання $\epsilon$ специфічним в розумінні органічного поєднання безваріантності фактографічного матеріалу із безмежною варіативністю його наукової інтерпретації, що в умовах цифровізації освіти вимагає як посилення уваги до навичок критичного аналізу інформації, так і розширення в змісті матеріалу творчого характеру. Історичним та культурологічним дисциплінам притаманна різноманітність первинних джерел, чим забезпечуються широкі можливості для застосування різноманітних методів інформаційного пошуку та аналізу, що сьогодні також найчастіше здійснюється в рамках можливостей, наданих цифровізацією освіти. Водночас історико-культурологічному знанню притаманні обов'язкові методологічні вимоги, які дозволяють подолати суперечність між об'єктивним та суб'єктивним. В умовах цифровізації освіти суттєво змінюється баланс між об'єктивним та суб'єктивним в суспільстві, а отже, і в історичному та культурному процесах. Відповідно зміст викладання дисциплін історико-культурологічного циклу варто оновлювати в напрямку 
Модернізація змістового наповнення дисциплін історико-культурологічного циклу в контексті цифровізації освіти

розвитку системності мислення, відповідальності суб'єкта історії та культури. Цифровізація освіти дає також широкі можливості для комунікації, академічної мобільності, індивідуалізації освітнього процесу, що також потребує зміни в змісті викладання. В перспективах подальших досліджень проаналізувати можливості міжпредметної інтеграції дисциплін історико-культурологічного циклу 3 іншими гуманітарними дисциплінами 3 точки зору оновлення змістовного наповнення відповідних курсів у вищому навчальному закладі.

\title{
СПИСОК ВИКОРИСТАНИХ ДЖЕРЕЛ
}

1. Биков, В. Ю. (2008). Інформатизація освіти. Енииклопедія освіти. В. Г. Кремень (Ред.). Київ, Україна: Юрінком Інтер.

2. Биков, В. Ю. \& Лапінський, В. В. (2012). Методологічні та методичні основи створення і використовування електронних засобів навчального призначення. Комп'ютер $y$ школі та сім 'ї, 2(98),3-66.

3. Воронова, Н. \& Гаврілова, Л. (2017). Цифрова культура як феномен сучасного інформаційно-комунікаційного педагогічного середовища. Засоби навчальної та науководослідної роботи, 48, 5-18. http://doi.org/10.5281/zenodo.1312912.

4. Дем’яненко, В. М., Лаврентьєва, Г. П., \& Шишкіна, М. П. (2013). Методичні рекомендації щодо добору і застосування електронних засобів та ресурсів навчального призначення. Комп'ютер у школі та сім' $i, 1,44-48$.

5. Карташова, Л. А., Бахмат, Н. В., \& Пліш, I. В. (2018). Розвиток цифрової компетентності педагога в інформаційно-освітньому середовищі закладу загальної середньої освіти. Інформачійні технології $і$ засоби навчання, 68 (6), 193-205.

6. Литвинова, С. Г. (2013). До питання експертизи якості електронних освітніх ресурсів. Інформачійні технологї̈ та засоби навчання, 34(2), 21-27.

7. Любарець, В. (2016). Створення електронної освітньої платформи ACCENT -шлях до якісної освіти. Вища освіта України, 3, 58-63.

8. Проект «Моя Україна. Берви». Взято з http://bervy.org.ua/

9. Brown, M. (2017). The NGDLE: We Are the Architects. EDUCAUSE Review, $11-18$. Взято 3 https://er.educause.edu/-/media/files/articles/2017/7/erm17411.pdf.

10. Dobbin, G. (2016). Exploring the Next Generation Digital Learning Environment: Opportunities and Challenges. Взято 3 https://library.educause.edu/resources/2016/6/exploring-thenext-generation-digital-learning-environment-opportunities-and-challenges

11. Lynch, M. (2018). What is the Next Generation of Digital Learning Environments? Взято $3 \mathrm{https} / /$ www.thetechedvocate.org/what-is-the-next-generation-of-digital-learning-environments/

\section{MODERNIZATION OF THE CONTENT OF THE DISCIPLINES OF HISTORICAL AND CULTURAL CYCLE IN THE CONTEXT OF DIGITALIZATION OF EDUCATION}

\author{
Nadiia Voronova \\ Dr. Hab. in Pedagogics, Associate Professor \\ Professor of Philosophy, History \\ and Social Sciences and Humanities Department, \\ SHEE "Donbas State Pedagogical University"
}

Професіоналізм педагога: теоретичні й методичні аспекти. Методичні матеріали до проєкту «Цифровий освітній простір: українсько-польський досвід». - Слов’янськ, 2021. 
Н. ВОРОНОВА, Н. ШАЛАШНА

Модернізація змістового наповнення дисциплін історико-культурологічного циклу

в контексті цифровізації освіти

\author{
Sloviansk, Ukraine \\ ORCID ID 0000-0001-7957-1655
}

voronova.ns@ukr.net

Natalia Shalashna

$\mathrm{PhD}$ in History, Associate Professor,

Associate Professor of Philosophy, History

and Social Sciences and Humanities Department

SHEE "Donbas State Pedagogical University"

Sloviansk, Ukraine

ORCID ID 0000-0002-9110-2680

n.shalashna@gmail.com

\begin{abstract}
The article outlines ways to modernize the content of the disciplines of the historical and cultural cycle in the context of digitalization of education. The peculiarities of historical and cultural disciplines, their influence on the development of the consciousness of applicants and the formation of relevant competencies are updated. Particular attention is paid to the analysis of the complexities and advantages of digitalization of education.

Analysis of publications. Problems of humanitarian education, cultural and historical training of future teachers with an emphasis on the content of the material and its impact on personal development are presented in studies by T. Vinnyk, I. Zyazyun, L. Kondratska, L. Masol, N. Myropolska, O. Shevnyuk. Conceptual problems of informatization of education have been studied in numerous scientific investigations of domestic (V. Bykov) and foreign (M. Brown, G. Dobbin, M. Lynch) scientists. Thorough investigations of domestic scientists are devoted to the use of information and communication technologies in higher professional education (V. Bykov, L. Gavrilova, S. Litvinova, V. Lyubarets), the formation of information and communication (digital) competence of future professionals (L. Kartashova).

The purpose of this article is to analyze the necessary areas of modernization of the content of teaching disciplines of the historical and cultural cycle in the context of digitalization of education.

Research results. The advantages of digitalization of education are determined. Individualization of training is an opportunity for each of the participants of the educational process to independently choose the pace of training, time of tasks, etc. Adherence to the principle of anthropologizing the content of historical and cultural knowledge in higher education implies a greater focus of the content of teaching on the individual as the main subject of the historical process. It is important to change the practices of communication in the educational process, both verbal and nonverbal. Expanding access to alternative sources of information is important for critical analysis of the information obtained, the criteria of probability, the reasons for possible bias of information. Attention is paid to the in-depth development of information competence, such as the ability to search, analyze the necessary information, the ability to independently produce and disseminate it. It is noted that historical and cultural educational components form a set of civic and social competencies. The list of electronic information and reference publications on history, culture and art, created on the basis of hypertext links and multimedia. A special place among them was occupied by multimedia encyclopedias, virtual museums (guides), virtual tours and galleries.

We conclude that, historical and culturological disciplines are characterized by a variety of primary sources. This provides ample opportunities for the application of various methods of information retrieval and analysis. The content of teaching the disciplines of the historical and cultural cycle should be updated in the direction of the development of systematic thinking, the responsibility of the subject of history and culture.
\end{abstract}

() ДВНЗ «Донбаський державний педагогічний університет» 
Н. ВОРОНОВА, Н. ШАЛАШНА

Модернізація змістового наповнення дисциплін історико-культурологічного циклу

в контексті цифровізації освіти renewal.

Key words: digitalization; individualization; anthropologization; content; history; culture;

\section{REFERENCES}

1. Bykov, V. Yu. (2008). Informatization of Education. Encyclopaedia of Education. V. H. Kremen (Ed.). Kyiv, Ukraine: Yurinkom Inter.

2. Bykov, V. Yu. \& Lapinskyi, V. V. (2012). Methodological and Methodical Bases of Creation and Use of Electronic Educational Tools. Computer in School and Family, 2 (98), 3-66.

3. Voronova, N. \& Havrilova, L. (2017). Digital Culture as a Phenomenon of Modern Information and Communication Pedagogical Environment. Means of Educational and Research Work, 48, 5-18. http://doi.org/10.5281/zenodo.1312912.

4. Demianenko, V. M., Lavrentieva, H. P., \& Shyshkina, M. P. (2013). Guidelines for the Selection and Use of Electronic Tools and Resources for Educational Purposes.. Computer in School and Family, 1, 44-48.

5. Kartashova, L. A., Bakhmat, N. V., \& Plish, I. V. (2018). Development of the Digital Competence of the Teacher in the Information and Learning Environment of the Institution of General Secondary Education. Information Technologies and Learning Tools, 68 (6), 193-205.

6. Lytvynova, S. H. (2013). To the Question of Quality Examination of Electronic Educational Resources. Information Technologies and Learning Tools, 34(2), 21-27.

7. Liubarets, V. (2016). Developing Electronic Learning Environment ACCENT - a Way to the Qualitative Education. Higher Education of Ukraine, 3, 58-63.

8. The project "My Ukraine. The Bervs". Retrieved from http://bervy.org.ua/

9. Brown, M. (2017). The NGDLE: We Are the Architects. EDUCAUSE Review. $11-18$. Retrieved from https://er.educause.edu/-/media/files/articles/2017/7/erm17411.pdf.

10. Dobbin, G. (2016). Exploring the Next Generation Digital Learning Environment: Opportunities and Challenges. Retrieved from https://library.educause.edu/resources /2016/6/exploring-the-next-generation-digital-learning-environment-opportunities-and-challenges

11. Lynch, M. (2018). What is the Next Generation of Digital Learning Environments? Retrieved from https://www.thetechedvocate.org/what-is-the-next-generation-of-digital-learningenvironments/

Матеріали надійшли до редакції 28.09.2021 p.

Професіоналізм педагога: теоретичні й методичні аспекти. Методичні матеріали до проєкту «Цифровий освітній простір: українсько-польський досвід». - Слов’янськ, 2021. 